\title{
Geomorphological hazards in a Mediterranean mountain environment - Example of Tétouan, Morocco
}

\author{
Hedvig PROKOS ${ }^{1}$, HasnaA B ABA ${ }^{2}$, Dénes LÓCZY³ and Younes EL KHARIM²
}

\begin{abstract}
The aim of this paper is to present the geomorphological hazards affecting the city of Tétouan, Morocco. The city is one of the most important urban centres in northern Morocco. Its geographical situation is strongly determined by the fact that in the last centuries it was built on the slopes of two ranges of the Rif Mountains, the Dersa to the North and the Ghorghiz to the South. These slopes relatively abruptly rise above the valley of the river Martil. Leaving the city, the river of only $22 \mathrm{~km}$ length flows into the Mediterranean Sea across the relatively wide Martil Plain. Given the geographical and geological setting of this area, heavy precipitation causes several problems during the humid period (November-April). Torrential rainfalls can have devastating effects on the community. Another severe problem lies in the hazard perception by the inhabitants, who lack the necessary information on geomorphic hazards and, as a consequence, keep on building their homes on unstable hillslopes. The working group in which authors participated had the objective to prepare a comprehensive documentation to inform the population on hazards, to make people aware of the vulnerability of the environment they live in.
\end{abstract}

Keywords: geomorphology, precipitation, urbanisation, landslide and flood hazards, Morocco

\section{Introduction}

In the developing world it is a common situation that unregulated urban development on mountain slopes induces major instabilities and hazards, while the local population is not aware of such problems (VERSTAPPEN, H.T. 1989; Alcántara-Ayala, I. 2002; SlayMAKER, O. 2010). Therefore, to avoid major disasters scientific research is only the first step, the education of the population on risks is also indispensable.

Morocco is one of the most hazard-prone Maghreb country, where dry spells, floods, landslides and locust invasions regularly cause great economic damage. Parts of the country are also exposed to seismic risk: 12,000 people lost their lives in a massive earthquake in the coastal town of Agadir in 1960. Cities and rural communities alike face the danger of sea-level rise and desertification as a result of climate change. As far as research into landslide hazards in Morocco is concerned, it has been mostly focused on seismic-induced landslides to date (HoussainI, S. and BAHI, L. 2014), but hydro-meteorological drivers are also widespread. The responsibility for disaster risk reduction lies with the Department of Environment at the Ministry of Energy, Water, Mines and Environment (MEWME), where the creation of a National Platform for Disaster Risk Reduction is coordinated (UNISDR 2012).

In September 2013 an international working group of volunteers from Europe with geography related degrees was working to-

\footnotetext{
${ }^{1}$ Earth Sciences Doctoral School, Department of Physical and Environmental Geography, University of Pécs. E-mail: hediprokos@gmail.com

${ }^{2}$ Université Abdelmalek Essaâdi, Faculté des Sciences, Tétouan, Morocco.

E-mails: hasnaa.baba@gmail.com,ykharim@yahoo.fr

${ }^{3}$ Department of Physical and Environmental Geography, University of Pécs. E-mail: loczyd@gamma.ttk.pte.hu
} 
gether with the students of the Department of Geology, University Abdelmalek Essaâdi, Faculty of Sciences, Tétouan. The aim of this cooperation was to create a document based on French methodology. In the popular document the sources of geomorphological hazards and the possible reconstructing and processes of prevention were detailed.

\section{Geographical setting}

Tétouan is a major urban centre of the Tingitane peninsula in northern Morocco. The second most populous city after Tanger (in 2014: 463968 ) and the $10^{\text {th }}$ by population in Morocco, administratively it is part of the Tanger/Tétouan region.

The city is locked between the mountain ranges of the Rif Mountains, the Jbel Dersa to the north and the Jbel Ghorghiz to the south, while the hills of Ouadrasse rise in the west (Karrouch, S. 2008) (Figure 1). The basin of the river Martil, where the city was built, opens to the east, towards the sea and the river val- ley continues in the alluvial Martil Plain (Comentale, B. 2007; Naoual, O.M. et al. 2009). This part of the country is strongly influenced both by the Alboran Basin of the Mediterranean and also by the Atlantic Ocean.

Similarly to other sections of the Rif Mountains (e.g. Azzouz, O. et al. 2002), the slopes of the mountain ranges near Tétouan are relatively steep, heavy rainfalls induce rapid runoff and some quarters of the city are regularly flooded. Further problems of urban development are the lack of available space and construction licencing policy.

Originally, until the $20^{\text {th }}$ century, the city spread on the foothills of the Jbel Dersa mountain range. Thereafter, urbanisation expanded onto the Martil Plain as well as onto the slopes of the Jbel Ghorghiz (CMECMED-Campus 2013).

\section{Geological setting}

In geological terms it spreads out on the Alboran lithospheric microplate in the Mediter-

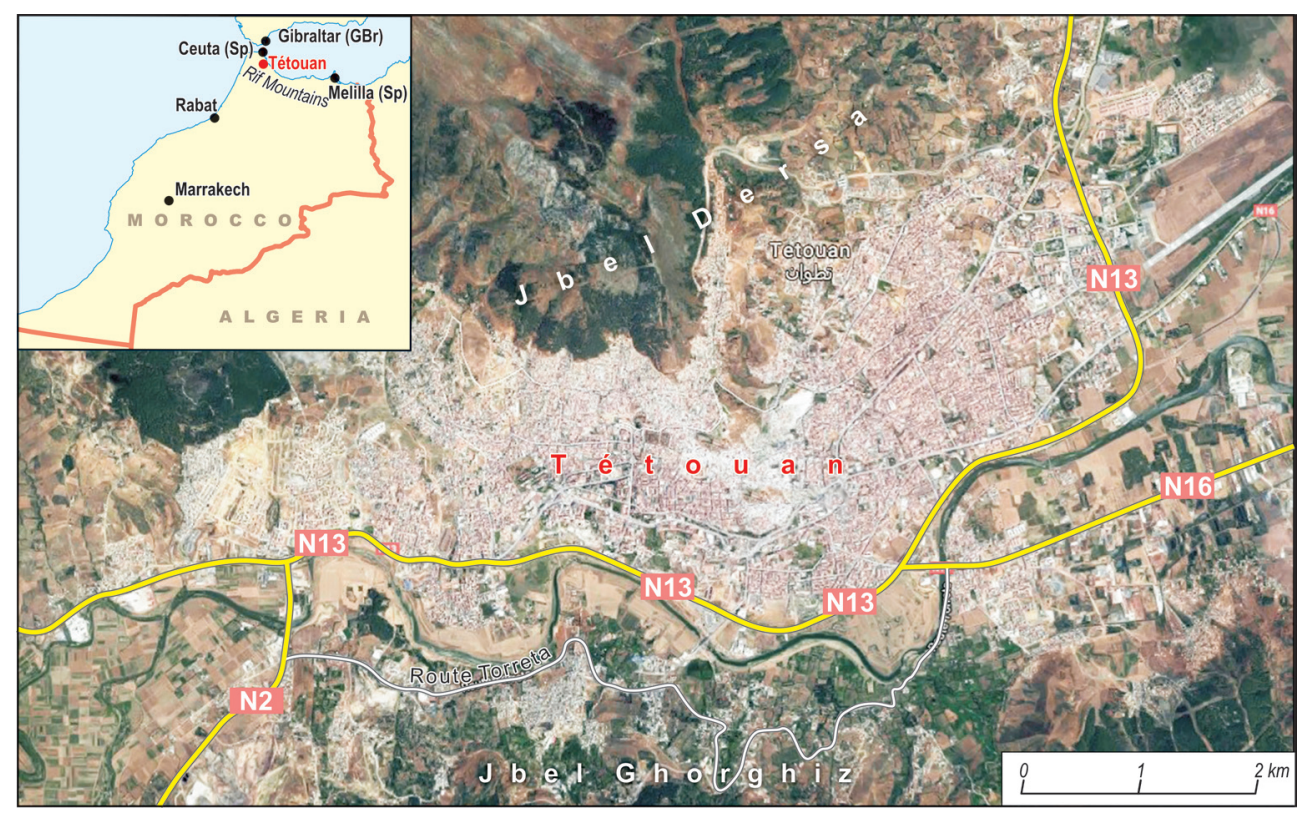

Fig. 1. Geographical setting of Tétouan. Source: InfoTerre and GoogleEarth, 2014. 
ranean, although is distinct from both Europe and Africa. Its stratigraphy can be related to the internal ranges of Rif Mountains as part of the Gibraltar Arc; together being part of the alpine origin Betic Cordilleras.

The prevailing surface rocks are limestone and flysch. The limestone ranges are not only important because of their susceptibility to rock fall and earthquake events, but also because they are easily dissoluble during wet periods. Further to this, the studied area belongs to the Central Calcareous Range (above 1,000 m), of which a $5 \mathrm{~km}$ long section is located to the north of Tétouan.

The existence of visible ancient erosional surfaces makes the Jbel Dersa differ both from other calcareous and from the mountainous ranges of the Tanger Peninsula in general (El Gharbaoui, A. 1986). These two residual levels can be described as follows: in the higher regions (500-550 $\mathrm{m}$ a.s.1.) a relatively flat plain inclining towards SE, supposedly from the Pre-Pliocene; and the other, lower-setting block (Samsa, $350 \mathrm{~m}$ a.s.1.) is a Late Pliocene surface disturbed by Villafranchian (MN16-17) and Quaternary processes. Similar to the Dersa Mountain, the Ghorghiz $(1,237 \mathrm{~m})$ also reveals some tectonic windows looking towards East.

According to the hydraulic drillings studying the upper $100 \mathrm{~m}$ of the basin deposits, the area is built up from Pliocene clayey-sandy deposits and Quaternary mud (Benmakhlouf, M. and Chalouan, A. 1995). The Tingitane Peninsula is dominated by mountainous landforms with several intramountain basins of different extension and valleys cutting through the pediments. These intra-mountain basins usually open to the Mediterranean Sea with varying width. Among others, so does the Martil Valley with its relatively wide alluvial plain. The diverse landscape comprises abrupt slopes and high relief (Figure 2). The prevailing limestone (in the North and South) and flisch (in the South) strata as well as the clays control the morphology and contribute to the occurrence of hazards in the region. Similarly to other basins in the Tanger-Tétouan region, an aver-

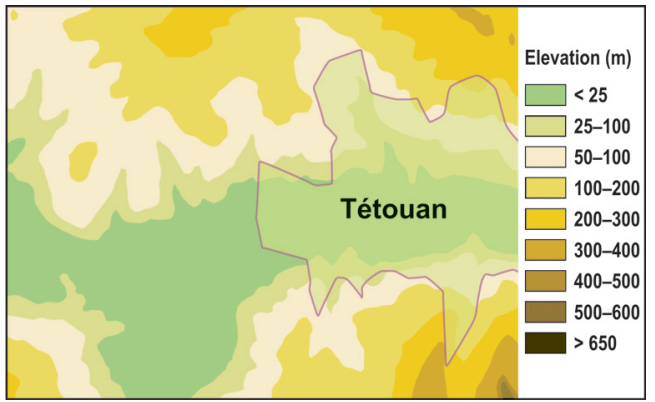

Fig. 2. Strait of Tétouan. A Digital Elevation Model of the western part of the Valley of Tétouan. Source: Modified after EgHAz, A. 2009 and DICRIM 2013.

age slope of $15-25^{\circ}$ is typical for higher elevations in the internal ranges of the western Rif Mountains.

In the flat alluvial plain (slopes below $1.5^{\circ}$ ) built up of sediments transported from the mountains streams show a meandering mechanism. Quoting Comentale, B. (2007), the only stream able to cut through the sandy alluvium is the Martil River. In historic times, the estuary was navigable, the fact that proves the recent filling of the basin. Due to the geographical and geological settings, agriculture suffers from several circumstances. In Morocco soils are eroded to rates that extremely exceed international standards as well as the rate of pedogenesis under the Mediterranean climate (RAISSOUNI, A. et al. 2012). Therefore, natural vegetation only appears in traces as shrub after a significant degradation.

\section{Social setting}

The city plays a significant role in the northern Tanger-Tétouan region since the $8^{\text {th }}$ century, the beginning of the Islamic period. Today it functions as a transiting spot between the Andalusian-Spanish and the Islamic world. Its population is on the increase. In the most typical Andalusian city of Morocco the Spanish influence can be observed not only on the ancient buildings but also in the society as many inhabitants speak Spanish. Actually, 
it is more widespread than the French language, which, beside the Arabic, is the official language of the Kingdom of Morocco.

The old city, the Medina, a UNESCO World Cultural Heritage site, was mostly built in the $15^{\text {th }}$ century. One of the smallest, and yet best preserved old towns, it is mostly inhabited by people of local origin. It is accessible via seven gates, of which Bab Okla, which leads to the city centre, is probably the best known. The growing population has been spread out on the hillslopes of both mountains during the past, especially since 2000. Construction licences do not stop the mindless urban sprawl. As a consequence, residential development already started on hazardous slopes. In addition, people living on the plain do not have much interaction with those living on the mountain slopes and, thus, when move to the new quarter, they are not informed about the potential hazards. The lack of this information makes them build on the affected areas. A possible reason for the missing information transfer can be found in the marked segregation of the population, i.e. the lack of communication between residents in the mountainous areas and those living in the city.

In developing countries vulnerability to natural hazards is much higher than in the developed world, and the impacts of certain threats or natural hazards are more significant. Among the explanatory factors are the level of infrastructure (road network, water supply system) and the practice of town planning. Also much depends on the consciousness of inhabitants concerning the particular consequences of construction and planning activities. All of these activities are limited by the low availability of financing resources, not to mention the rapid population and urban growth.

In technical context, planning regulations and institutional frameworks are increasingly associated with the concepts of risk and sustainability, but in most countries sustainable development has only become an explicit focus of public policy within the last 10-20 years (HiggitT, D. 2010).

\section{Climatic factors of flood hazard}

The studied area is one of the most humid regions in the country. Rainfalls under the semi-humid Mediterranean climate with slight Atlantic influence are also influenced by the basin-like morphology next to the Mediterranean Sea. The steep slopes around the basin considerably increase the runoff in the narrow Martil Valley. Annual mean precipitation is ca. $650 \mathrm{~mm}$ (ranges between 650-800 $\mathrm{mm}$ ), however, according to the Moroccan Ministry of Energy, Mines, Water and Environment it often exceeds 1,000 mm and can even reach 1,800 mm. Karrouch, S. (2008) claims that the majority of the precipitation falls in the period from December to March. Also, referring to ChrAA, A. (2006), this period can be extended from late October to mid-February, when ca. 75 percent of the annual precipitation falls mainly in the form of torrential rains. This is the period when flood damage is concentrated.

In the Rif Mountains, due to the dominance of clayey sediments and the high relief subsurface runoff becomes subordinate (CHRAA, A. 2006). Water saturated slopes with angles above $15^{\circ}$ and high landslide hazard are common along the newly built road network. The length of the river Martil is only $22 \mathrm{~km}$ with a mean annual discharge of $19.2 \mathrm{~m}^{3} / \mathrm{s}$ (ranging from $2.75 \mathrm{~m}^{3} / \mathrm{s}$ to $47.3 \mathrm{~m}^{3} / \mathrm{s}$ ). The axial river receives the cumulative water and sediment discharges that their tributary catchments provide. They are highly sensitive to variations in the relative amounts of water and sediment (LEEDER, M. et al. 1998), as a consequence of what the river builds a vast alluvial fan of Quaternary deposits before flows into the Mediterranean Sea. The majority of the tributaries issue from a limestone range (from $140 \mathrm{~m}$ to $1,090 \mathrm{~m}$ ) close to the city (Amraoui, A 1988). The river has a relatively small watershed area $\left(1,220 \mathrm{~km}^{2}\right)$, yet the intersection of minor streams (Mhajrat, Kheims, Chekkoûr) which join to make up the Martil river form a hydrographical node of particularly high flood hazard. From the node, the discharge increases significantly, 
often causing huge flooding in the city (most recently in August 2013). According to the Department of Environment at the MEWME (2013), the province of Tétouan is among those with the highest risk of inundation within the Tanger-Tétouan region, where as many as 53 flood events have been recorded in the past decade (1993-2013).

In all scenarios temperatures continue to rise worldwide, with global mean temperatures averaging plus $2{ }^{\circ} \mathrm{C}$ to $4{ }^{\circ} \mathrm{C}$ by the end of the century, accompanied by changes in the amounts and patterns of precipitation (Borgatti, L. and Soldati, M. 2010). Therefore we cannot neglect the predictable changes revealed by climate models when talking about geomorphologic hazards. The quoted authors add that in the future precipitation can fall in any time of the year and with increased frequency and intensity. Particularly concerning the rainfall regime of Mediterranean area (Rianna, G. et al. 2014), as a consequence of changes in precipitation, the main triggering factor, the extension, frequency and intensity of landslides could also modify in the near future. (The interactions between these parameters see in the chapter of results.) However, assessment of the impact of climate change on landslide is difficult, because major variations are expected on the regional scale (BumA, J. and DeHn, M. 1998).

\section{Methods}

The base of our prepared document was the data we have collected on field, derived from local studies as well as the data provided by the local governmental bodies. However, the amount and depth of the provided data cannot be considered sufficient. Regarding the technical part, we have supplemented our data with fieldwork in September 2013 at some of the affected sites. According to BorGAtTI, L. and Soldati, M. (2010), there are several risk assessment, catastrophe prevention methods which can be used for a certain natural hazard in a given geographical environment.
According to the principles of zonation in the context of physical geography, zonation of a natural hazard requires the integration of primary and auxiliary causative factors, clustering of similar units, identification of dissimilar units, and the multi-level classification of mapping units (NI, J.R. et al. 2006). Furthermore, it is important to recognize the causes which trigger sudden mass movements and lead to catastrophic events, to know about past and present incidents which may help to predict, and at last to recognize the level of the hazard. This method is called Rapid Zonation of Abrupt Mass Movement Hazard (RZAMH). It provides a relatively complex multi-level classification system for abrupt mass movement hazards. This kind of classification also involves human impacts.

Beside RZAMH, several methods to predict soil loss erosion exist. The soil loss is caused mainly by agriculture activities. USLE (Universal Soil Loss Equation) does not involve human impacts like RZAMH, however, can predict the expected amount of soil loss. Climatic factors can be somewhat predicted and once past events are reconstructed they may help us to identify current areas prone to landslides. This landslide susceptibility modelling method was presented at the international seminar, "Journées des Géosciences de l'Environnement" transcript written by SADIKI, A. et al. 2011. Its aim in the first phase, was to "determine landslide susceptible areas based on the study of relationships between spatial distribution of past landslides and the cartographic set of landslide predisposing factors" (SADIKI, A. et al. 2011) This method, called Informative Values (VI), consists of superposing several thematic layers in a GIS database. Each of the presented layers represents a potential parameter what can trigger a landslide, ranged into classes. Landslide susceptibility occurs at the intersection of the most susceptible prone areas of each layer (Figure 3).

Using GIS software, the combination of the above mentioned datasets may present a thorough and accurate picture of the mass movement susceptible areas. The authors (KHALI 


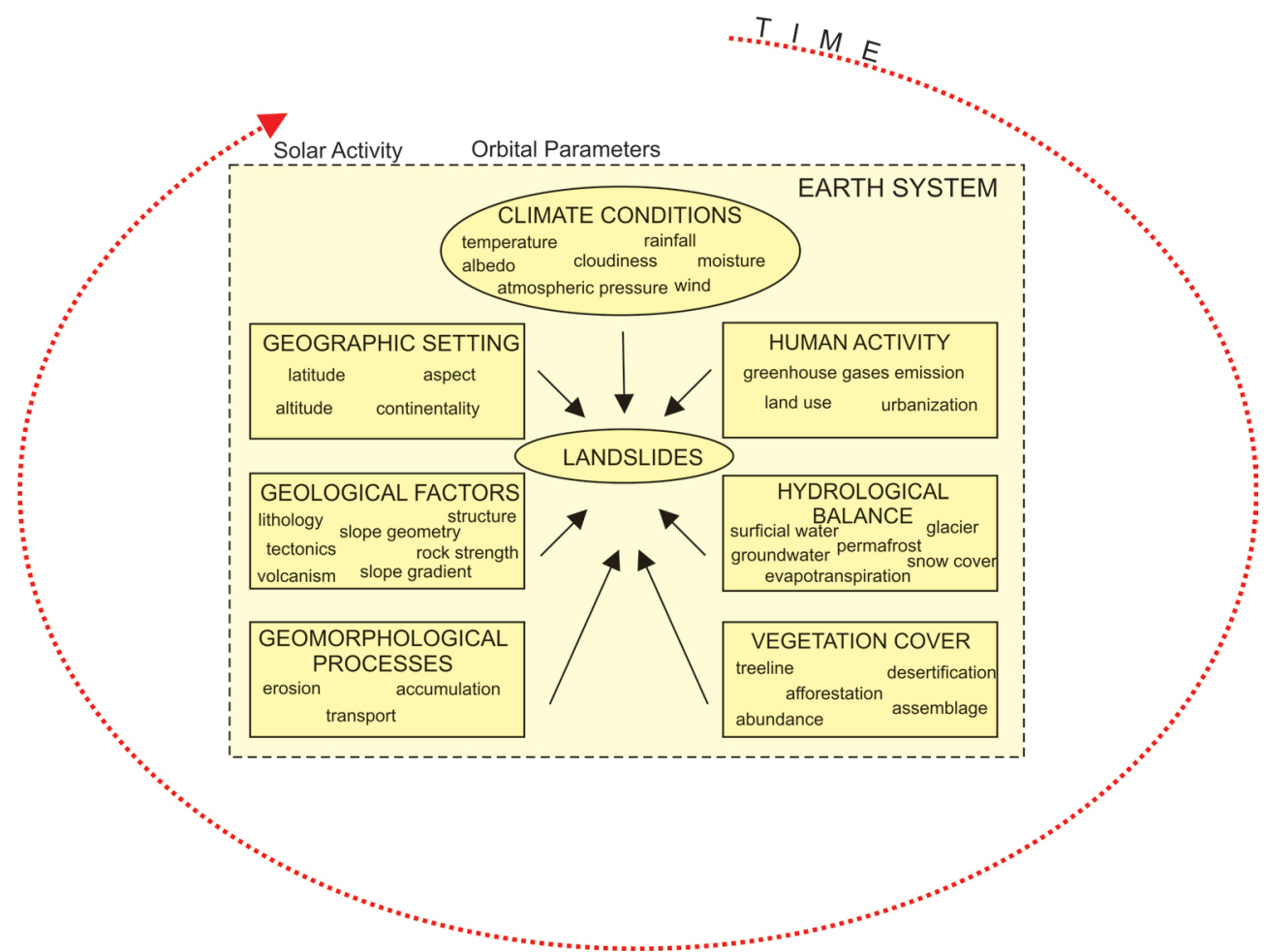

Fig. 3. Preparatory factors and triggering causes of slope instability with special emphasis on climate conditions. Source: modified after BorgatTI, L. and Soldati, M. 2010.

IssA, L. et al. 2014) estimated the average annual soil loss triggered by mass movements using the USLE method, and got a result of 36 $\mathrm{t} /$ ha/year (ranges between $12 \mathrm{t} / \mathrm{ha} /$ year and 120 $\mathrm{t} /$ ha/year). Their study area was the Khmiss watershed, which is situated in the northern section of the Martil watershed, as being part of the streams forming the Martil River.

The main objective of the survey of natural hazards was the compilation of a popular summary, following the example of the French Document d'Information Communal sur les Risques Majeurs (DICRIM), in English: Communal Informational Paper about the Major Hazards (Dictionnaire Environnement 2010). The government decree no. 90-918 about the DICRIM was approved on 11 October 1990. It states that the mayor has the responsibility to assess possible hazards which may affect the community and also to create a document on them. The decree expresses that all inhabitants have the right to dispose of all the necessary information, which is of four main types:

- Knowledge on the natural and technologic hazards of the commune;

- Measuring works and/or any attempt made by the commune;

- Emergency plan in case of danger;

- Display flyers/plans about the instructions which came into force on 27 May 2003.

The affected towns/cities and land proprietors have to put out a display plan about the instructions needed, well before informing the public. These instructions are detailed in the DICRIM.

Beyond these instructions, it is the responsibility of the mayor to decide what this doc- 
ument will contain. Normally, it contains the following points:

- General information on the hazard itself, whether it is natural or technological by origin;

- The state of the perception of each hazard;

- Every relevant event happened in the past within the commune;

- Preventive, protective, surveying and securing activities already made by the commune, in order to protect the people in the best way possible.

The answers to the questions represent the information the mayor can provide to the inhabitants about the commune, either permanent or temporary. These are the questions what need to be answered by everyone - either individual, business managers, or institution representatives (of communal or parental use) - for their own security in case of danger. The last part "what do I have to do to limit the consequences of risk?" shows the importance of sharing the current status of hazards between authorities and population. The political success of natural risk prevention will obviously be a social success for each participant of the commune, too. Thus, province of Chefchaouen (MAstere, M. et al. 2013) 45 percent of gravitational movements (landslides included) occur on agricultural land and 26 percent of them under dense forest coverage. Within the group of mass movements, landslides and land subsidence caused by undermining are the most common hazards regardless of soil coverage type. The old city centre protected by wall, the Medina, was built upon travertines, therefore, the hazard of pothole collapse is relatively high. In case of risk or vulnerability, the parameters shown in Figure 4 are relevant for the prediction of disasters.

As it is shown in Figure 4, the whole area is affected by several, in some parts by multiple hazards, mainly concentrated in the western districts. A simple table provided by the authorities of the community lists the affected areas, whereas it is well visible that both rural and urban areas are affected (Table 1).

The spatial distribution of landslide hazard is closely associated with the distribution of travertines, which is mostly limited to the area of the Medina. According to ChraA, A. (2006), quoting El Gharbaoui, A. (1981), the Tingitane Peninsula geomorphologically can be classified into the following categories: this requires both consciousness and capability to reduce vulnerability from the part of the individuals.

\section{Results and discussion}

Due to its geographical and geological setting, people living in Tétouan are exposed to multiple hazards. The most severe of them are landslides, therefore, an amount of about 50 percent of the budget designated for public reconstruction works is dedicated for mitigation works in the area of Tétouan and Chefchaouen. It concerns especially the main roads. According to a recent study from the

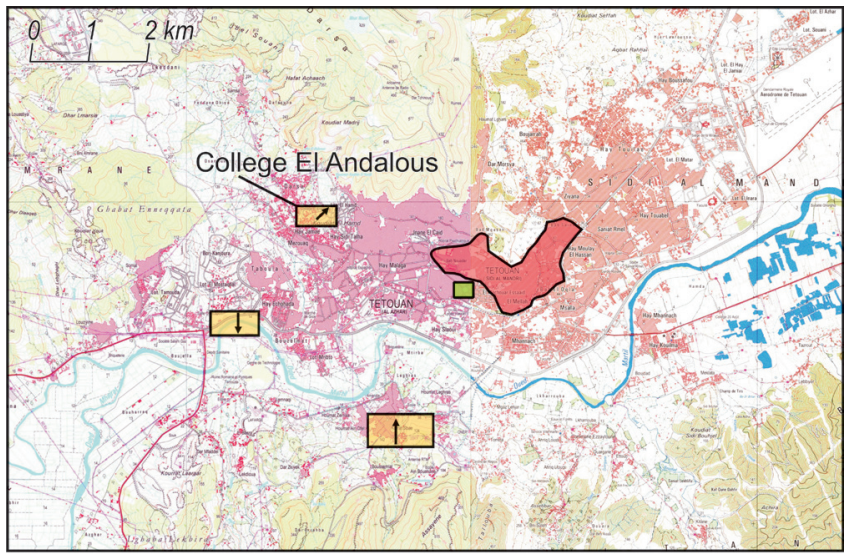

Slides, indicating the direction Gravitational potholes Travertines - Medina

Fig. 4. The localization of some of the natural hazards affecting the city of Tétouan. Source: BАвA, H. and Prokos, H. 2013. 
Table. 1. Landslide affected sites in the community area of Tétouan, 2004.

\begin{tabular}{|c|c|c|c|}
\hline \multicolumn{2}{|r|}{ Zone } & Sites under risk & Village \\
\hline \multicolumn{2}{|l|}{ Urban } & \multicolumn{2}{|l|}{$\begin{array}{l}\text { - Kourrat Sbaa } \\
\text { - Khandak Zarbouh } \\
\text { - Koudiat El Hamd } \\
\text { - Along the Oued Samsa } \\
\text { - Bouenan } \\
\text { - Bou Semlal } \\
\text { - Zkiek }\end{array}$} \\
\hline \multirow[b]{3}{*}{ Rural } & Rural community & $\begin{array}{l}\text { - Al Alyeene } \\
\text { - Onsar } \\
\text { - Ajiibech } \\
\text { - Tayenza } \\
\text { - Ikhalfin }\end{array}$ & $\begin{array}{l}\text { - Alyeene } \\
\text { - Mallaleene } \\
\text { - Seddina } \\
\text { - Beni laït } \\
\text { - Beni Said }\end{array}$ \\
\hline & \multicolumn{3}{|c|}{ In the neighbourhood of dam Nakhla } \\
\hline & Routes & \multicolumn{2}{|c|}{$\begin{array}{l}\text { - National route } \mathrm{n} .2 \text { from Spirada to Lhilah. } \\
\text { - Regional route } \mathrm{n} .417 \text { (between PK } 8+500 \text { and PK 17+380). } \\
\text { - Regional route n. } 414 . \\
\text { - Provincial route no. } 4702 \text { (route Beni Idder). } \\
\text { - Third-class route going to Jbel Ghorgiz. } \\
\text { - At some parts along the route in direction of Ken Karrich until the community } \\
\text { border of the town of Chefchaouen }\end{array}$} \\
\hline
\end{tabular}

- erosional basins with low hills within the mountain foreland;

- limestone-dolomite foreland with gentle slopes to the South of Tétouan and ranges of subvertical carbonate strata of the Haouz mountain range (highly prone to landslides).

The mass movements observed may be separated into slow, mostly continuous movements and rapid episodic movements.

\section{A) Slow, mostly continuous movements}

a) Landslides. As mentioned earlier, landslides are the most common type of hazard in the Tanger-Tétouan region. This is due to the common occurrence of clayey beds, the geological setting and the torrential floods following heavy rainfall events. Inactive shear planes reactivated by anthropic effect should also be noted.

Example 1: Korrat Sbae. A continuously renewed unstable slope causing many problems for constructions and for the main road with the same name. Induced by both natural and anthropic processes (leaking sewer system and lack of subsurface canalisa- tion), deep-seated rotational landslides occur. According to a survey made in 2008, 2 percent of the buildings collapsed, 7 percent considerably and 12 percent moderately affected by the slides (Photos 1-4).

Example 2: Taboula, Road no. 2. Close to Korrat Sbae, this slide is situated in the cemetery. It is less deep, but is active in almost every year. Retreating gradually in spite of restoration works, it causes constant trouble to the authorities. The municipality is planning to build a protective wall.

b) Collapse. Processes normally caused by loading or water pumping, but may occur also as a consequence of subsurface dislocation of matter. Most commonly affects densely built areas, where soft and plastic soil (e.g. clay) can be found. As an example the collapse at Onsar au Haouz in 1946 can be cited after which event the village had to be evacuated.

c) Piping - subsurface changes in volume of matter caused by swelling and shrinking of clays. This process normally works at the points where single-story buildings join each other. It is due to the low weight and rigid parameters of clay (BABA, H. et al. 2013). A lack of geotechnical preventive measures must be 


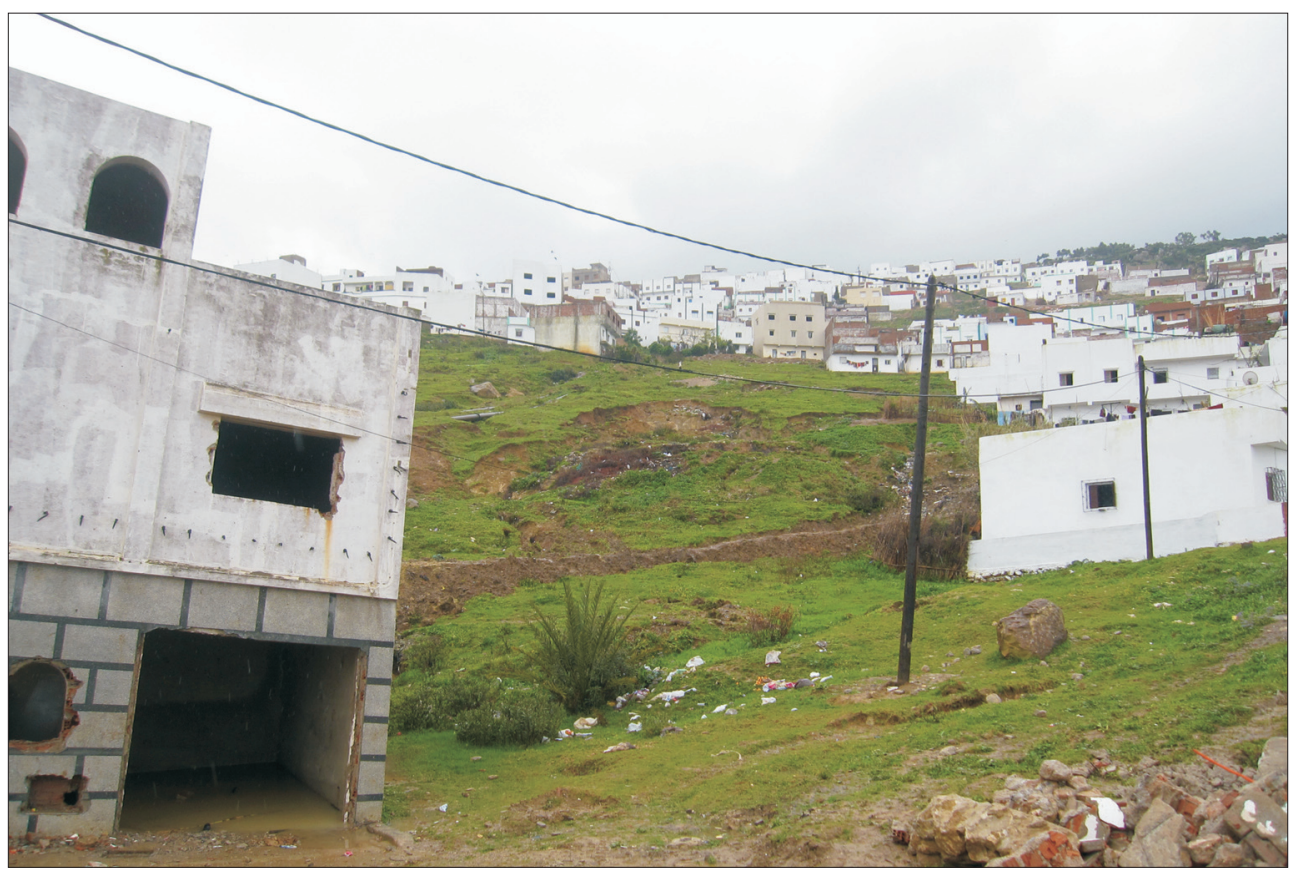

Photo 1. Consequences of landslides in Korrat Sbae before terrain management, 2012. Source: Faculty of Sciences, Tétouan, 2012.

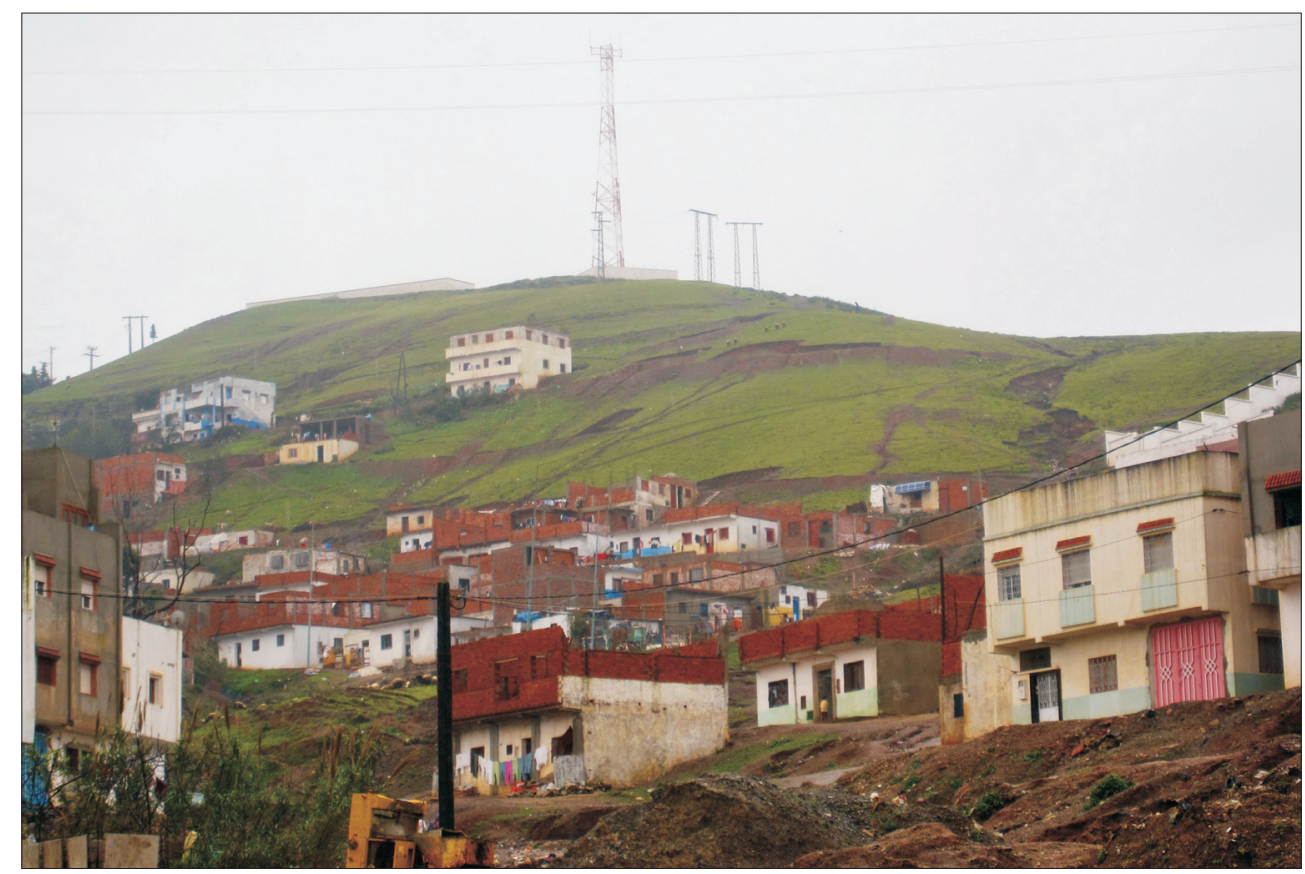

Photo 2. Areas prone to landslides in Korrat Sbae. Source: Faculty of Sciences, Tétouan, 2012. 


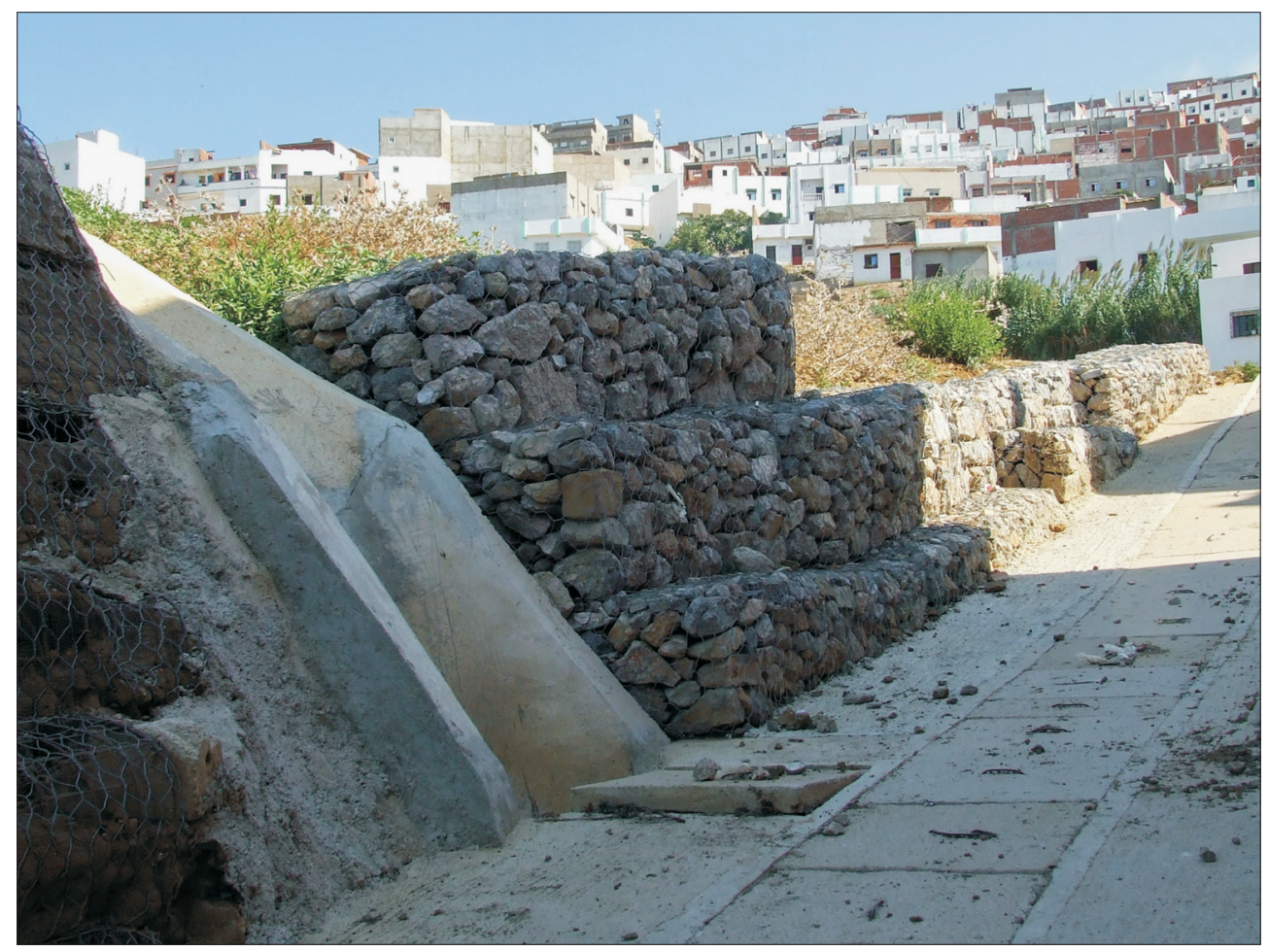

Photo 3. Protective wall between the road and the slope after landscaping $(10 \times 10 \mathrm{~m})$. (Photo by Proкos, H. 2013)

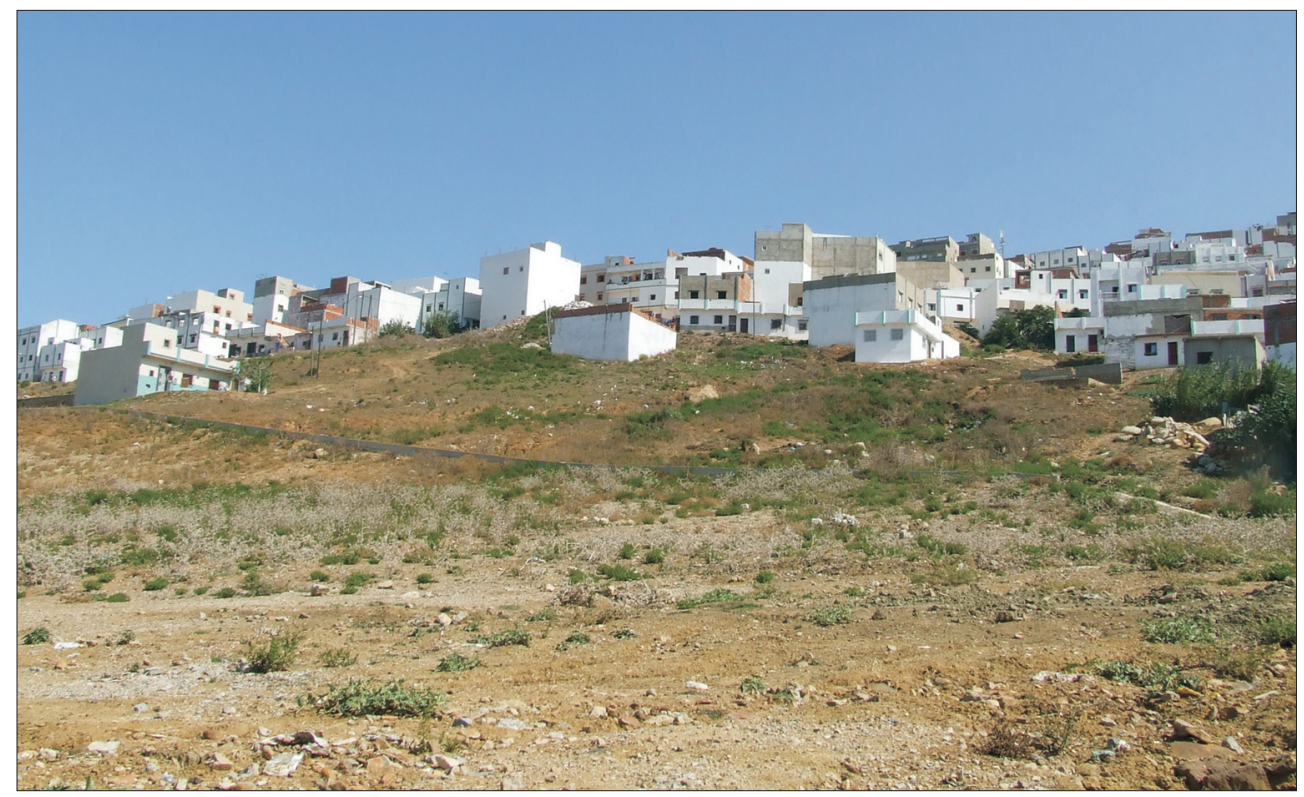

Photo 4. Korrat Sbae after landscaping (Photo by Prokos, H. 2013) 
noted. The geological structure of the basin provides good permeability in the upper sandy-silty layers, hence the actual abundance of rainwater varies in the low-lying flat areas with the weather situation.

\section{B) Rapid episodic movements}

a) Rockfalls, topples. Affects mainly the steep slopes of the limestone range, thus means a potential hazard for the land properties found close to these slopes, in foothill areas. Such movements are relatively rare, but still happen time to time. As an example, this block of rock ca. $4 \mathrm{~m}$ high rolled down into Bouanan, $3 \mathrm{~km}$ to the South of Tétouan, in 1993.

b) Gravitational potholes. Due to lack of geotechnical measurements, the presence of underground cavities under the travertinebased Medina (Photo 5) and El Ensanche districts is only an assumption (BABA, H. et al. 2013). However, events that happened in recent years tend to prove that underground cavities exist. An example to support this is the pothole collapse in 1990 on the Moulay El Mahdi Square.

\section{Conclusions}

The geographical setting and the geological structure detailed above reflect a relatively varied relief. In addition, to this come unbalanced, extreme rainfall events due to the region's climatic situation. Examples brought from Mastere, M. et al. 2013, only indicated to show that the whole area has a somewhat hazardous geological setting with its susceptibility to flood hazards and mass movements. However, the comparison with the region of Chefchaouen (see MAstere, M. et al. 2013) and the region of Bab Mrouj (see Abdellatif, T. 1997) shows that Tétouan is in a much more hazardous situation.

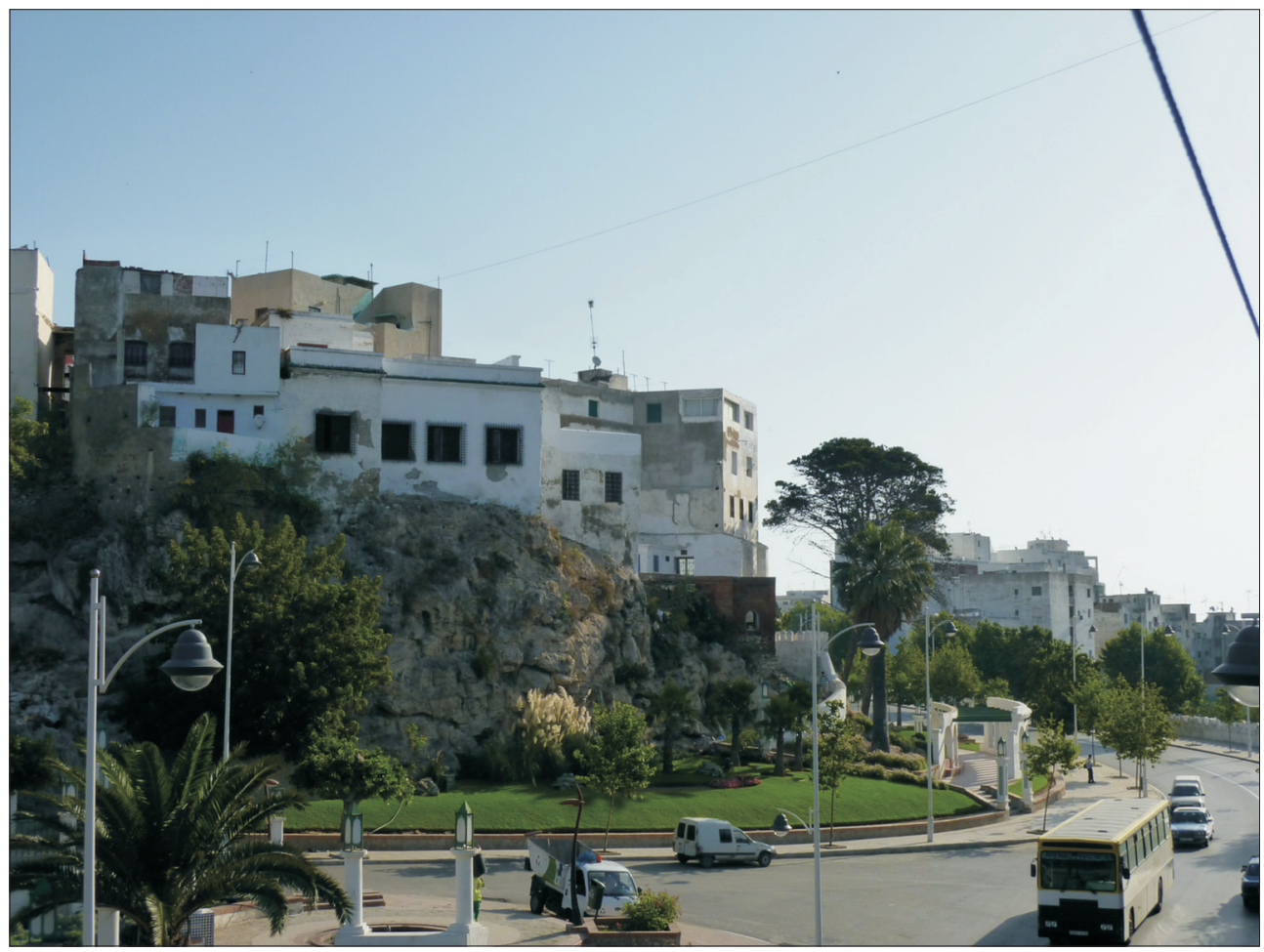

Photo 5. Houses built on travertines in the downtown. Source: Faculty of Sciences, Tétouan, 2013. 
As soil coverage in accordance with geological features and land use percentages are similar in the Rif regions, the explanation should lie in other factors e.g. anthropogenic, besides geologic. According to HiggitT, D. (2010), increased vulnerability can be explained not only by environmentally-geomorphological factors, but also by the lifestyle of the society, the increasing numbers of population who tend to live in areas with mass movement hazard.

The complexity of this problem lies in the fact that geomorphological hazards extend over agricultural land which badly affects the economic status of the sector. Decision-making tools such as detailed geomorphologicalgeological mapping and an effective distribution of information are needed. Attempts have been made to restore and protect structures in these areas, although they are not supposed to suffice in the future.

Although, several projects have already been dedicated to target this problem, population growth and urbanisation is set to continue at higher rates and the municipalities are not yet properly prepared for the predictable consequences. In addition to applying tools like construction licences and restrictions, the affected areas should undergo professional surveys to reveal environmental conditions comprehensively. As the city is among the most developed urban centres in the region, all efforts will be made to mitigate the hazards in the near future.

\section{REFERENCES}

Abdellatif, T. 1997. Quelques exemples de mouvements de terrain dans le PréRif oriental (Maroc). - Méditerranée. Impact anthropique en milieu méditerranéen 86. (1-2): 61-66. doi:10.3406/medit.1997.2991

AlCántara-Ayala, I. 2002. Geomorphology, natural hazards, vulnerability and prevention of natural disasters in developing countries. Geomorphology 47. 107-124.

Amraoui, A. 1988. Hydrogéologie de la Dorsale Calcaire du Rif-Maroc septentrional. PhD Thesis. Grenoble, Université Jospeh Fourier, Institute of Geology.
Azzouz, O., El Fellah, B. and Chalouan, A. 2002. Processus de glissement dans le Massif de Bokoya (Rif interne, Maroc): exemple de Cala Bonita. Bulletin de l'Institut scientifique, Rabat, section Sciences de la Terre 24. 33-40.

Baba, H., Prokos H. and Frinmat, T. 2013. Les risques mouvements de terrain. Campus 2013. Manuscript. Tétouan Université Abdelmalek Essaâdi, Faculté des Sciences.

Benmakhlouf, M. and Chalouan, A. 1995. Evolution Néogène du bassin de Tétouan-Martil, Rif septentrional, Maroc. Geogaceta 17. 98-100.

Borgatti, L. and Soldati, M. 2010. Landslides and climatic change. In Geomorphological Hazards and Disaster Prevention. Eds.: AlcántaRa-Ayala, I. and Goudie, A.S., Cambridge, Cambridge University Press, 87-96.

Buma, J. and Dehn, M. 1998. A method for predicting the impact of climate change on slope stability. Environmental Geology 35. (2-3): 190-196.

ChraA, A. 2006. Le risque des mouvements des versants: Le contexte géologique de l'instabilité du massif rocheux de Bouanane, le versant sud de la cluse de Tétouan (Rif occidental, Maroc). MSc Thesis. Tétouan, Université Abdelmalek Essaadi, Faculté des Sciences.

CME - CMED - Campus 2013. Présentation du campus Tétouan. Présentation de la région Tanger-Tétouan. Tétouan, Université Abdelmalek Essaadi, Faculté des Sciences.

Comentale, B. 2007. Géomorphologie et remblaiment récent de la plaine de Martil (région de Tétouan, Maroc septentrional). MSc Thesis. Brest, Université Brest. http://hal.univ-brest.fr/docs/00/28/38/94/PDF/plaine_de_Martil_06-06-2007.pdf. Accessed 05.11.2013.

Dictionnaire Environnement 2010. DICRIM. http://www. dictionnaire-environnement.com/ document_information_communal_sur_les_risques_majeurs_dicrim_ID1395.html

Eghaz, A. 2009. Mouvements de versants dans le perimetre urbain de la ville de Tétouan (Rif Nord Occidental Maroc). MSc Thesis. Tétouan, Université Abdelmalek Essaadi, Faculté des Sciences.

El Gharbaoui, A. 1986. L'homme et la montagne dans la dorsale calcaire du Rif (Maroc septentrional). Revue de l'Occident musulman et de la Méditerranée 41-42. Désert et montagne au Maghreb, 197-208.

HigGitT, D. 2010. Geomorphic Hazards and Sustainable Development. In Geomorphologic Hazards and Disaster Prevention. Eds.: Alcántara-Alaya, I. and Goudie, A.S., Cambridge, Cambridge University Press, 257-268.

Houssaini, S. and BahI, L. 2014. Observation and Study of Landslides Affecting the Tangier - Oued R'mel Motorway Segment. International Journal of Environmental, Chemical, Ecological, Geological and Geophysical Engineering 8. (7): 527-530. http://www. water.gov.ma/userfiles/file/4_M\%C3\%A9diterrand\%C3\%A9f.pdf. Accessed 05.11.2013. 
Karrouch, S. 2008. Contexte structurale des travertins de la ville de Tétouan (Rif septentrional, Maroc). BSc Thesis. Tétouan, Université Abdelmalek Essaadi, Faculté des Sciences.

Khali Issa, L., Raissouni, A., Moussadek, R. and El Arrim, A. 2014. Mapping and assessment of water erosion in the Khmiss Watershed (North Western Rif, Morocco). Current Advances in Environmental Science 2. (4): 119-130.

Leeder, M. R., Harris, T. and Kirkby, M.J. 1998. Sediment supply and climate change : implications for basin stratigraphy. Basin Research 10. 7-18.

Mastere, M., Van Vliet-Lanö̈, B. and Ait Brahim, L. 2013. Cartographie de l'occupation des sols en relation avec les mouvements gravitaires et le ravinement dans le Rif nord-occidental (Maroc). Géomorphologie: relief, processus, environnement 19. (3): 335-352. doi: 10.4000/geomorphologie.10328

Naoual, O.M., Targuisti, K. and Jamal, S. 2009. Evaluation de la qualité des eaux dans les systèmes fluviaux du Rif (cas de la rivière Martil) et étude de la biodiversité des communétes de macroinvertébres. Segundo Congreso Internacional Sobre Geologia y Mineria en la Ordenación del Territorio y en el Desarrollo, Utrillas, p. 8, 96-98. http://www. sedpgym.es/descargas/libros_actas/UTRILLAS_ 2009/08.UTRILLAS.pdf. Accessed 05.11.2013

Ni, J.R., LiU, R.Z., WaI, O.W.H., Borthwick, A.G.L. and GE, X.D. 2006. Rapid zonation of abrupt mass movement hazards: Part I. General Principles. Geomorphology 80. 214-225.

Office National des Hydrocarbures et des Mines 2013. http://www.onhym.com/G\%C3\%A9ologieduMa rocDomainesstructuraux/tabid/582/Default.aspx. Accessed 07.12.2013.

Raissouni, A., Khali Issa, L., El Arrim, A., MaÂtouk, M. and Passalacqua, R. 2012. GIS-Based Model to Assess Erosion Sensitivity in Northern Morocco. Laou Watershed Case Study. International Journal of Geosciences 3. 610-626. doi: 10.4236/ijg.2012.33061
Rianna, G., Zollo, A., Tommasi, P., Paciucci, M., Comegna, M. and Mercogliano, P. 2014. Evaluation of the effects of climate changes on landslide activity of Orvieto clayey slope. The Third Italian Workshop on Landslides. Procedia Earth and Planetary Science 9. 54-63.

Royaume du Maroc 2013. Les Bassins Hydrauliques du Maroc. Bassins cotières méditerranéens, 119-127.

Royaume du Maroc 2013. Rapport National sur l'État de l'Environnement: Régoin Tanger - Tétouan. http://www.environnement.gov.ma/fr/component/ content/article?id=1077:region-tanger-tetouan. Accessed 21/08/2016.

Royaume du Maroc. Ministere de l'intérieur, Wilaya de Tétouan D.E.G.R. 2004. Gestion des risques dans la province de Tétouan (Séismes, Incindies, Inondation, Mouvements de terrains, Pollution accidentelles). Manuscript

SAdikI, A., FAleh, A. and Mesrar, H. 2011. Landslide susceptibility modelling using GIS and statical method in the Oued Larbaa basin (Eastern Rif, Morocco). Journal of Materials and Environmental Science 2. (S1): 526-531.

SlaymAKer, O. 2010. Mountain Hazards. In Geomorphological Hazards and Disaster Prevention. Eds.: Alcántara-Alaya, I. and Goudie, A.S., Cambridge, Cambridge University Press, 33-48.

UNESCO World Heritage sites 2013. http://whc. unesco.org/en/list/837 Accessed 24.10.2013.

UNISDR 2012. Morocco to create National Platform for Disaster Risk Reduction. Geneva, UN Office for Disaster Risk Reduction, News archive. https://www.unisdr.org/archive/ 25414. Accessed 24.10.2013.

Verstappen, H.T. 1989. Geomorphology, natural disasters and global change. Symposium on Aerospace Survey and Natural Disasters. International Institute for GeoInformation Science (ITC) Journal 3-4. 159-164. 